\title{
William F. Cody, alias "Buffalo Bill"
}

\section{By E. A. Johnson}

There are but few people past the age of fifteen in the United States who never have heard of "Buffalo Bill." Fewer still know that this once famous character was an Iowa product. He was born on a Scott county, Iowa farm, February 26, 1846, the same year Iowa was admitted to statehood. Likewise, is it true that a vast majority of those who claim any semblance of acquaintanceship rely on having once seen or heard of him as the head of the great Wild West show that was one of the major attractions of the first World's Fair in Chicago in 1893.

As a recent resident of North Platte, Nebraska, that for many years was his home, I became imbued with a desire to learn something more of his life and accomplishments. At the city library I was able to secure a copy of his autobiography carefully written, two biographies by other authors, and better yet, engaged in conversations with several fellowtownsmen who personally knew him many years ago.

Cody states in his autobiography that his parents were quiet, honest God-fearing Ohio people, who came to Iowa in 1840. Following removal of his parents to Kansas in 1854, the subject of this brief sketch, then was eight years of age. From that time onward Cody's autobiography and that of his various biographers fail to agree in many important details. After the age of ten years he refused to attend school and his education in the commonly accepted sense was very rudimentary.

Soon after his tenth birthday he found employment as a sort of messenger and general utility boy with the then well-known freighting firm of Russell, Majors \& Waddell, who operated a train of twenty-five wagons, each drawn by six yoke of oxen from St. Joe, Missouri, 
to the Pacific coast. No railroad had yet crossed the Missouri river and as there was a decisive westward movement, this firm was doing an enormous business. (Incidentally, it might be stated that Harry Russell, now a retired business man of Des Moines, is a son of the senior member of the above mentioned firm.)

According to the history of that period, that section of the country was experiencing exciting and troublesome times. The Civil war was in the making and the extension of slavery was the subject of much bitterness. Cody's own father was anti-slavery and while not advocating abolishment in slave states, he bitterly opposed the extension of slavery into the state of Kansas, and firmly so stated when it was demanded of him to publically make known his position on that question. For this he was attacked by proslavery ruffians from the slave state of Missouri and injured to a degree that later resulted in his death.

In addition to the slavery dispute, hostile and warlike Indians were prevalent in nearby localities. Another element of discord was the difficulties of the Mormons. Young Cody, now eleven years old, after the death of his father, became the bread winner for his widowed mother, a younger brother and two sisters. Due to the threat of civil war, the Indian depredations and Mormon trouble great numbers of troops were assembled at various points westward, all of whom had to be fed and provided with arms and needed supplies.

Immediately following the outbreak, congress ordered an expedition under command of Gen. Albert Sydney Johnston to proceed. Russell, Majors \& Waddell were awarded a contract for transporting supplies and cattle to feed the army. The twenty-five wagons loaded with supplies of food and munitions, and cattle driven behind, started on the expedition. After a day's journey the caravan was attacked by Indians. They were successfully warded off until nightfall, but while encamped it was again attacked. During the 
fight at a favorable opportunity Billy Cody fired his gun; an Indian bit the dust, and eleven-year-old Cody killed his first Indian. From this time on he was a man of the Plains, and fighting Indians and white outlaws was almost a daily occurrence.

In 1860, the firm of Russell, Majors \& Waddell organized the "Pony Express" and in his fifteenth year Cody became one of the first riders. On the route from St. Joe to Sacramento, California, a distance of 2000 miles, the schedule time at first was ten days to cover the distance, but as time passed, the schedule was shortened to eight days. Cody relates in his autobiography that he was one of the relay riders to carry Lincoln's Inaugural address from St. Joe to Sacramento in seven days and seventeen hours.

Cody states that in 1861 he joined a local company known as Red-Legged Scouts to co-operate with the regular army to protect the Kansas border against slave-state Missouri bandits, such as Quantrell, James boys, Younger brothers and other guerrilla bands, molesting Union settlers. Cody was a loyal American and for many years was a Union scout and spy in the South and guide employed by the U. S. government. As such he enjoyed the full confidence and friendship of army officials including Generals Sherman, Sheridan, Custer and many others.

In 1872, Cody entertained Gen. P. T. Sheridan and Grand Duke Alexis, the Russian nobleman, when he as leader engaged in a grand buffalo hunt in western Nebraska. And again in 1874, with General Sheridan with a company of New York gentlemen, including James Gordon Bennett of the New York Herald, Leonard Jerome, General Fitzhugh, General H. E. Davis, General Stager of the Western Union, Carroll Livingston, Captain Rogers, Samuel Johnson of the Chicago Journal and several others, Cody conducted an extended buffalo hunt, covering a period of two weeks, during which the buffalo population of western Nebraska suffered a serious decline. On another occasion Cody 
was host to a pair of English nobility on a hunting expedition.

As to Cody's prowess as a hunter, he tells in his autobiography that in 1867 , he entered into a contract to supply buffalo meat for the builders of the Kansas Pacific Railway and that covering a period of seventeen months he shot and killed 4280 bison.

That Cody was loyal to his country has never been questioned, but he married a southern lady rebel, a Miss Frederici of St. Louis, of whom he says, "I am proud to say that after fifty years of married life she is as strongly 'Secesh' as ever." She lived many years in North Platte and I doubt if one could find in that city of 20,000 population any man or woman who would speak a word of criticism.

One episode occurred in the career of Cody, which in present day political life is hard to believe. In the year 1872, during a slack season in his duties as scout he returned to his North Platte home on a short vacation. On his arrival he was greeted with a cheerful "How do you do, Honorable," by a group of men in front of a store. Continuing down the street everyone he met addressed him as "Honorable." Entering the mayor's office, he was greeted with a hearty handshake and a "Good morning, Honorable." "What does this 'Honorable' mean?" he demanded. Replied the Mayor, "Of course while away as scout you may not have heard, but while you were gone, you were nominated and elected to represent the 26th district of Nebraska in the state legislature." Cody replied, "That is highly complimentary and I appreciate it, but I am no politician and shall tender my resignation." And resign he did.

Cody from boyhood had an ambition to be a showman, but through the years other more important matters occupied his time and talents, yet that yearning for publicity and its rewards did not wane. A reproduction of the exciting incidents in which he had been a part, a vision of pioneer life, he believed would be 
popular and profitable. So, in 1882 , on his big ranch adjoining the city of North Platte he began the organization of his wild west show, assembling Indians, cowboys, horses, ponies, buffaloes and other wild animals, old stage coaches and other equipment typifying pioneer life. Then followed long days of training in acting, marksmanship, horseback riding, in pantomime battles with savage Indians, stage coach robberies, fights with outlaws, gamblers and many other scenes experienced in pioneer life. In May 1884, at Omaha, Nebraska, he made his initial presentation. Then followed exhibitions in many of the larger cities in the United States.

In March 1886, he chartered the steamer "Nebraska" and set sail for England. He put on his first foreign show in the big London amphitheater, where it was repeated daily for several weeks to record-breaking crowds, which included the crown heads of the kingdom. During his stay in London two and a half million people saw the show. From London he went to Paris for a six months engagement. Following this, he made a tour of Europe, showing in Spain, Italy, Austria, Hungary and Germany, after which the show returned to the United States and opened for a sixmonths stand at the Columbia Exposition in April 1893.

Although the show was a great success, had made millions for the producers, Cody at length found himself a bankrupt and on January 10, 1917, died at the home of his sister in Denver, Colorado, and was buried in a grave blasted out of solid granite atop Lookout mountain.

\section{Iowa Leadership in Sorghum}

In the production of sorghum syrup Iowa led the nation in 1952, with 380,000 gallons, according to the $U$. S. department of agriculture. In the second place was Tennessee with 360,000 gallons. The total production in the United States last year was 2,595,000 gallons. The dollar valuation of Iowa's crop was $\$ 931,000$. 
Copyright of Annals of Iowa is the property of State of Iowa, by \& through the State Historical Society of Iowa and its content may not be copied or emailed to multiple sites or posted to a listserv without the copyright holder's express written permission. However, users may print, download, or email articles for individual use. 